Gift Mugano $^{1}$

Durban University of Technology,

Faculty of Management Sciences,

Department of Public Management and Economics

Durban (South Africa)
616.98:578.834]:338.248.8

Review scientific paper

Submitted 27/07/2020

Accepted 21/08/2020

doi:10.5937/socpreg54-27700

\title{
THE ECONOMY NEXUS OF THE COVID-19 PANDEMIC
}

\begin{abstract}
The COVID-19 pandemic, which is unprecedented in human history and has to date resulted in 15.8 million confirmed cases with 640,016 deaths, has seen governments undertaking strict lockdown measures which not only affected local business activities but also disrupted global value chains resulting in massive economic implications. The purpose of this paper is to review the impact of the COVID-19 pandemic on the economy with a special focus on the African continent. Because the coronavirus pandemic is still evolving and its duration is uncertain, it is difficult to accurately quantify the economic implications of the pandemic. As a result, this paper used the scenario basis analysis as well as extensive literature on the subject. The results show that the pandemic, although it has devastating social impacts due to loss of human life, it has also presented serious economic challenges which inter alia include economic recession, reduced trade volumes and subdued financial flows. Because of globalisation, Africa is not immune to these challenges. As noted in this paper, major economic activities and sources of foreign exchange in Africa such as the tourism sector, export of commodities, external finances and local business activities were negatively affected, resulting in most African economies falling into recession which has wiped out economic gains of the last ten years as noted by the International Monetary Fund. In mitigating this pandemic, African countries should use incentive packages to save businesses as well as institute a number of fiscal measures such as tax waivers and engage international development partners for bail out.
\end{abstract}

Keywords: Economy, COVID-19 Pandemic

\section{Introduction}

The coronavirus pandemic was first reported on 31 December 2019 in Wuhan City, Hubei Province of China as a cluster of pneumonia cases of unknown cause (United Nations Development Programme, UNDP, 2020). Since then, the globe has witnessed phenomenal spread of the coronavirus and the disease that causes it, that is, COVID-19. On 30 January and 11 March 2020, because of the fast spread of the disease, both in terms of geographic

1 gmugano@gmail.com 
coverage and casualties, the World Health Organization (WHO), declared the coronavirus outbreak, a public health emergency of international concern and a pandemic, respectively (UNDP, 2020). To date, as on 26 July 2020, the pandemic has seen confirmed cases rising to 15.8 million people, with casualties of 640,016 deaths (World Health Organisation, 2020).

Given the nature of the disease, there are certain epidemiological features that remain ambiguous hence at this stage it is impossible to determine with certainty how the pandemic will evolve. This paper reviews the economic impacts of COVID-19 with a special focus on the African economy.

In this paper, because of scarcity of data and the fact that the impact of COVID-19 is still evolving, it is difficult to quantify the actual and potential impact of the COVID -19 pandemic. In this regard, using existing literature from reputable sources such as the World Bank, International Monetary Fund (IMF), UNDP and other think tanks, the paper focuses on understanding the possible economic implications as well as scenario analysis with a view to establishing the impact of the pandemic on the global economy and the African continent. The paper is structured as follows: section two discusses the impact of COVID19 on the global economy; section three discusses the impact of COVID-19 on African economy and section four presents the concluding remarks and policy priority.

\section{Current Global Economic Context}

The COVID-19 pandemic is destroying the global economy in an unprecedented manner. The level of economic destruction is phenomenal and has never been observed since the Great Depression of the 1930s and the recent global economic crisis of 2008. Sadly, this is taking place at a time when the world economy is struggling to fully recover from the 2008 crisis.

As observed, the pandemic has a devastating effect both on human life as characterised by massive mortalities witnessed, as well as economic impacts through disruption of global value chains which accounts for about $50 \%$ of world trade, sharp fall in commodity prices, drop in foreign exchange receipts, sudden fall in tourism arrivals, decline in foreign financial inflows and frozen labour markets as a result of lockdowns (African Union, 2020).

\subsection{Plummeting of Commodity Prices}

Because of a sudden fall in demand due to reduced travel, oil prices plunged down from US $\$ 67$ per barrel to US\$30 per barrel, that is, by more than $54 \%$ (African Union, 2020). Past experience has shown that drop in prices of oil has devastating effects on oil producing economies. For example, the decline in crude oil prices which was noted by the end of 2014 resulted in massive decline in gross domestic product (GDP) for the Sub-Saharan Africa from $5.1 \%$ in 2014 to $1.4 \%$ in 2016. During this period, crude oil prices dropped by as many as $56 \%$ over seven months (African Union, 2020). Notably, since the price of crude oil has plummeted by more than $54 \%$ in three months, the current decline in crude oil prices has shown to be very fast thereby presenting a gloomy picture, that is, gloomier than 2014, in as far as the GDPs of oil producing countries is concerned.

However, in trying to mitigate the continuous fall in crude oil prices, major oil producers came up with proposal to cut crude oil production by 1.5 million barrels per day by June 2020 (African Union, 2020). The expectations were that non-OPEC states such as 
Russia would follow the trend. Unfortunately, this did not happen because on 8 March 2020 Saudi Arabia made an announcement that it would increase production, which resulted in escalation of oil wars as non-OPEC members retaliated, thus causing further plummeting of oil prices (African Union, 2020).

\subsection{Impact on the Aviation and Travel Industry}

In 2019 , the aviation industry recorded US $\$ 830$ billion in revenue. In the absence of the COVID-19 pandemic, the sector was projected to US $\$ 872$ billion of sales revenue in 2020. However, because of the coronavirus which resulted in abrupt lockdowns and massive restrictions on travel, on 5 March 2020, the International Air Transport Association (IATA) projected that the aviation industry is likely to run a loss of US $\$ 113$ billion as a result of the disruptions which were caused by COVID-19. Recent statistics shows that aviation and travel industries are expected to gross up US\$419 billion in 2020, that is, a $50 \%$ decline of 2019 sales revenue (IATA, 2020).

Likewise, the tourism sector is facing similar problems. The tourism sector is anticipated to witness fall of $60-80 \%$ in tourist arrival, as well as revenue in the region of US\$ 910 billion - US\$ 1.2 trillion, that is, almost two thirds of US\$ 1.5 trillion revenue generated in 2019, in foreign currency receipts in 2020, as a result of the disruptions which comes with COVID-19 pandemic (United Nations World Tourism Organisation, UNWTO, 2020). When past market trends are considered, this loss in revenue amounts to five to seven years-worth of growth which will be lost as a result of the COVID-19 pandemic. The combined effect of this loss, from employment perspective, is that the tourism and hospitality industries are anticipated to shed of several millions considering the fact that $80 \%$ of all tourism businesses are small-and-medium-sized enterprises (SMEs) with limited financial capacity to absorb the shocks of sudden fall in revenue (UNWTO, 2020).

At a global level, the hotel and hospitality industries are likely to lose about $20 \%$ of its annual revenue. However, the top tourism destinations such as Cambodia, Vietnam, Thailand, France, the United Kingdom, Italy, the USA, Mexico, China, Turkey and Germany together with travel supporting one in ten jobs (319 million) in the world and generating $10.4 \%$ of global GDP are likely to lose between $40 \%$ and $60 \%$ of annual turnover as a result of the travel restrictions.

\subsection{Impact on Global Financial Markets}

As a result of the disruptions caused by the COVID-19 pandemic, global stock markets witnessed massive losses in their history in decades. For example, in what is called the Black Monday episode of March 9, stock markets such as the Dow Jones lost close to 3000 points in one day while FTSE plunged by about $5 \%$ and witnessed a staggering US\$ 90 billion loss in one day (see Table 1. Likewise, the banking sector has lost about $40 \%$ of its value in just one month and the trend is still bearish.

\subsection{Global Trade}

On 23 June 2020, the World Trade Organization (WTO) projected that global trade volumes are likely to decline by $18.5 \%$ in 2020 , with a rebound expected in 2021 . This new projection shows a downward revision from the WTO's 8 April 2020 estimates which was 
rather more optimistic as it has forecasted that global trade volumes might fall by $12.9 \%$ due to the economic impact of COVID-19, as shown in Table 2]

Although there is a high degree of uncertainty regarding the duration and economic impact of the COVID-19 pandemic, the WTO argues that the impact of the pandemic on global trade volumes will exceed the drop in global trade witnessed during the height of the 2008-2009 global financial crisis (WTO, 2020).

With respect to exports, using the optimistic scenario, as noted by the WTO (2020), North America is anticipated to record a $-17.1 \%$ decline in exports in 2020. In the same vein, the pessimistic scenario shows that North America could record fall in exports by $40.9 \%$ in 2020. Using the optimistic scenario, South and Central America, Europe, Asia and other regions, are anticipated to record decline in exports $-12.9 \%,-12.2 \%,-13.5 \%$ and $-8.0 \%$, respectively (WTO, 2020) (see Table 2.

Likewise, based on the pessimistic scenario, total imports in North America, South and Central America, Europe, Asia and other region are expected to plummet by $-33.8 \%$, $-43.8 \%,-28.9 \%,-31.5 \%$ and $-22.6 \%$, respectively (WTO, 2020) (see Table 2 .

Since there is a casual link between exports and growth, using the pessimistic scenario, all the regions, that is, North America, South and Central America, Europe, Asia and other regions are anticipated to shrink by $-9.0 \%,-11 \%,-10.8 \%,-7.1 \%$ and $-6.7 \%$, respectively (WTO, 2020) (see Table 2.

Overall, the WTO (2020) observed that global economy is expected to bounce back in 2021 as both exports and imports are expected to recover thereby sparing economic growth.

\section{Review of the Economic Impacts of COVID-19: Evidence from Africa}

Because of globalisation, Africa has found itself integrated with the global economy through international trade as well as migration. This therefore makes Africa vulnerable to the COVID-19 pandemic. In this regard, Africa suffers from both exogenous and endogenous effects of the pandemic (African Union, 2020).

The exogenous effects, which are external factors, are as a result of decline in trade flows between Africa and other continents which subdued supply of tourists; remittances, official development assistance, foreign direct investments and other financial flows.

With respect to endogenous effects, the African continent witnessed slowed economic activities as a result of internal factors which are caused by spikes in the spread of the virus and the restrictions which were pursued by various governments with a view to containing it. For example, the lockdowns which were applied by most African governments resulted in serious disruption of economic activities resulting in decline in domestic demand and tax revenue. Subsequent sections present the impact of COVID-19 pandemic on the tourism sector, commodity prices, exports, economic growth and external funding.

\subsection{Loss of Activity and Jobs in the African Tourism and Travel Industry}

Because of worldwide application of travel restrictions and lockdowns, the African tourism sector, which is one of the backbones of African economies, suffered massive losses as a result of sudden decline in tourist arrivals. Specifically, IATA notes that air transport alone in Africa which is estimated at US\$55.8 billion represents 2.6\% of African GDP and supports 6.2 million jobs. Although at this stage it is difficult to quantify the potential 
impact of COVID-19 pandemic, the travel restrictions negatively affected international airlines including African top airlines such as Ethiopian Airlines, Egypt Air, Kenya Airways, South African Airways, etc.

The IATA noted that, because of COVID-19 pandemic and subsequent travel restrictions, $80 \%$ of the bookings were cancelled while international bookings in Africa in March 2020 and April 2020 declined by 20\% (IATA, 2020). Likewise, domestic bookings fell by 15\% in March 2020 and 25\% in April 2020. Sadly, between February 2020 and March 2020, ticket refunds shot up by $75 \%$ in 2020 compared to the same period in 2019 (01 February-11 March), resulting in loss of revenue by US $\$ 4.4$ billion by African airlines (IATA, 2020).

Nigeria, Ethiopia, South Africa, Kenya, and Tanzania. Tourism employment comprises more than 20 percent of total employment in Seychelles, Cape Verde, Mauritius and Zimbabwe are amongst African states whose economy is significantly driven by the tourism sector, that is, both directly through foreign exchange earnings and through the value chains and downstream industries (African Union, 2020). Specifically, from a job creation perspective, the tourism sector absorbs more than a million people in each of the following countries: South Africa, Kenya, Nigeria, Ethiopia, and Tanzania (African Union, 2020). In Seychelles, Cape Verde, São Tomé and Príncipe, and Mauritius, the tourism sector employs more than $20 \%$ of total employment (African Union, 2020).

During the recent crisis, that is the 2008 global financial crisis and the 2014 commodity price shock, African tourism experienced losses of up to US\$7.2 billion. Building on this, under the average scenario, African Union (2020) argues that the tourism and travel sector in Africa is likely to lose at least $\$ 50$ billion as a result of theCOVID-19 pandemic and more than 2 million jobs.

\subsection{African Exports}

Recent statistics from the UNTACD shows that for the period (2015-2019) total Africa trade averaged at US \$ 760 billion per annum which represents $29 \%$ of Africa's GDP. In the same UNCTAD report, because of low levels of industrial transformation, infrastructure, limited financial and monetary integration and existence of rampant tariff and non-tariff barriers, intra-African trade accounts for only $17 \%$ of total trade of African countries. With $83 \%$ of African trade being traded outside the African continent, makes African economy vulnerable to the exogenous shocks such as the COVID-19 pandemic.

Interestingly, Africa's major trading partners are the United States, European Union and China. Ironically, as noted in Table 3 , total imports in North America, South and Central America, Europe, Asia and other region are expected to plummet by $-33.8 \%,-43.8 \%$, $-28.9 \%,-31.5 \%$ and $-22.6 \%$, respectively (WTO, 2020). Although it is difficult to quantify the exact impact of fall in exports from African economies as a result of massive decline in imports from these major trading partners, it is undeniable that Africa will witness a sharp decline in exports in 2020.

From exports of crude oil perspective, as noted in section 2.1, the price of crude oil has drastically fell to below US\$30 per barrel, which has a direct impact on export receipts for countries such as Algeria, Angola, Cameroon, Chad, Equatorial Guinea, Gabon, Ghana, Nigeria, and the Republic of the Congo (African Union, 2020).

In addition, there was a general fall in demand for crude oil, which resulted in some African exporters getting stuck with their product. For example, as on $4 \mathrm{March}$, about $70 \%$ 
of the April 2020-loading cargoes of crude oil from Angola and Nigeria were still unsold whilst other oil exporting countries from Africa such as Gabon and Congo had difficulties getting buyers. South Sudan and Eretria, in particular, were affected by the collapse of trade and broken supply chains in China (United Nations Economic Commission for Africa (UNECA), 2020). This is particularly so because China imports account for $95 \%$ and 58\% of all of South Sudan's and Eritrea's exports (UNECA, 2020).

This double tragedy of reduction in crude oil prices as well as sudden shocks from plummeting demand have far-reaching implications on African oil exporting economies.

However, the impact of reduced foreign currency earnings as a result of fall in prices of crude oil has different implications on African economies. For example, in South Africa, oil exports represent $3 \%$ of GDP and as such, even though it is significant considering the fact that the country is already in recession, its overall impact is marginal. However, for countries such as Nigeria and Angola, whose oil exports represents $90 \%$ of total exports and contribute more than $70 \%$ of the national budget, the fall in prices of crude oil by more than $54 \%$ is likely to be catastrophic to these economies (UNECA, 2020).

Rightly so, the UNECA (2020) estimated that the expected losses related to the collapse of the prices of crude oil are around US $\$ 65$ billion, of which up to US $\$ 19$ billion of the losses are expected in Nigeria. Ironically, Nigeria, it its current national budget, it was prepared under the assumption that crude oil prices was anticipated to be averaging around US $\$ 67$ per barrel. Since the price has fell by more than $54 \%$, it therefore forces countries which are backed up by oil exports to reduce their revenue forecasts and cut expenditure for at least two quarters (OECD Development Centre, 2020).

However, this has a net effect of reducing the foreign exchange reserves of the oil exporting countries and as well as their capability to implement their development programmes aimed at easing the impact of the COVID-19 pandemic.

Outside trade in crude oil, Africa's imports were observed to have been adversely affected by the COVID-19 pandemic. Because of disruption of production and trade, a number of African countries which include South Africa, Zimbabwe, Ghana and Rwanda, for example, witnessed a sudden fall in imports which resulted in shortages of basic commodities which are traditionally imported from China thereby causing a surge in inflation in these countries (African Union, 2020).

\subsection{Africa's External Financing}

Over the years, a number of countries in Africa heavily relied on external financing in financing their current account imbalances. These external sources of finance, inter alia, include remittances, foreign direct investment, official development assistance, external debt and portfolio investments. Nevertheless, because of expected recessions or economic meltdown in source countries, the supply of remittances, foreign direct investments, portfolio investments, external debt and official development assistance to Africa is likely to be elusive (African Union, 2020).

\section{(a) Remittances}

Remittances, which for the last ten years have consistently contributed about a third of total external financial flows to Africa, are expected to fall drastically because of subdued activities in most advanced and emerging economies which host the African diaspora. 
The studies by Mugano (2018) and African Union (2020) show that the contribution of remittances as a share of GDP exceed 5\% in 13 African countries while in some countries range as high as $23 \%$ in Lesotho and more than $12 \%$ Comoros, the Gambia, and Liberia. Ironically, when combined, Egypt and Nigeria account for $60 \%$ of Africa's remittances inflows. These countries are anticipated to face serious shocks and vulnerabilities as a result of fall in diaspora remittances.

(b) Foreign Direct Investment

UNCTAD (2019) noted that foreign direct investment to African economies witnessed an upward increase by $11 \%$ notwithstanding the fact that globally FDIs took a nosedive. This increase was mainly contributed by increase in investments into natural resources and economic recovering in South Africa. As noted by UNCTAD (2019), the top 5 recipient countries were in 2017: Egypt ( $\$ 6.8$ billion, $-8.2 \%$ ); South Africa ( $\$ 5.3$ billion, $+165.8 \%)$, Congo (4.3 billion, $-2.1 \%$ ), Morocco ( $\$ 3.6$ billion, $+35.5 \%$ ), and Ethiopia ( $\$ 3.3$ billion, $-17.6 \%$ ).

Now, with the uncertainties over the length of the COVID-19 pandemic and with general consensus centred around a scenario of the spread of the pandemic expected to run throughout 2020, FDIs are expected to drop by between $-5 \%$ and $-15 \%$. This is particularly so because signals from statements issued by top 100 multinational enterprises (MNEs), as noted by OECD, indicated serious desire to slow down capital expenditures as part of mitigation measures against reduced earnings as a result of the COVID-19 pandemic (UNCTAD, 2020).

In addition, African economies such as Nigeria have already large-scale capital withdrawals. For example, the All Share Index in Nigeria registered its worst performance in the last ten years March 2020 as overseas investors pulled out. Based on the foregoing discussion, experts project that Africa may lose up to $15 \%$ of the FDI inflow into the continent as a result of the COVID-19 pandemic.

\subsection{The Impact of COVID-19 on Economic Growth in Sub-Saharan Africa}

Sub-Saharan African economies are expected to shrink by $3.2 \%$ in 2020 as a result of the adverse effects of COVID-19.As noted by the International Monetary Fund (2020), in 2020 Sub-Saharan African economies will have a GDP that is US\$243 billion smaller than projected in October 2019. The major downward revisions are mainly driven by tourism dependent economies such as Tanzania, Zimbabwe, Comoros and Mauritius as well oil exporting countries which are largely dominated by Nigeria and Angola (IMF, 2020).

Interestingly, countries such as Côte d'Ivoire, Rwanda, Senegal and Uganda, which are more diversified, are expected to withstand the adverse impact of COVID-19 and are expected to remain positive in 2020 (IMF, 2020).

A closer review of major economies in SSA shows that South Africa, Nigeria and Angola are in recession.

South African economy is expected to contract by $8 \%$ mainly as a result economic shutdown which was enforced in April-May 2020 with a view to containing the COVID19 pandemic. Likewise, real GDP per capita is expected to shrink by $9.4 \%$ in 2020 , as result of disruption of business (see Table 3). However, in 2021, as a result of improvement of business activities and confidence, the South African economy is expected to rebound by $3.5 \%$ (see Table 3 ). 
Nigeria, because of loss of foreign exchange on the back of the tragedy of reduced economic activity, reduced global demand of crude oil and crude oil prices, is expected to contract by $5.4 \%$ in 2020 (see Table 3 (IMF, 2020). The country is expected to register a $2.6 \%$ growth rate in 2021 on the back of rising global demand and prices of crude oil.

Like Nigeria, Angolan economy is anticipated to contract by $4 \%$ as a result of fall in global prices of crude oil and demand, reduced domestic activities as a result of the lockdowns and tight credit conditions (IMF, 2020). Likewise, real GDP per capita in Angola is expected to shrink by $6.8 \%$ in 2020 (see Table 3 . On the back of firming oil prices and improvement in business activities the Angolan economy is anticipated to grow by $3.25 \%$ in 2021 .

Overall, in Africa the COVID-19 pandemic is expected to shrink real per capita GDP by $5.4 \%$ in 2020 which will bring the per capita GDP back to its level in 2010 (IMF, 2020). As the IMF put it:

"The crisis impact is set to wipe out almost 10 years of progress in development in Africa."

\section{Conclusion and Policy Priority}

The COVID-19 pandemic undoubtedly brought economic and social hardships across the globe. In as much as it is a global pandemic, African economies, because their over-reliance on export of few lines of commodities, limited intra-Africa trade and weak macroeconomic environment, have been severely hit by the pandemic. To make matters worse, external sources of financing in the form of FDIs, remittances, portfolio investments, official development assistance and external debt were found to be elusive in Africa in this current year as result of the coronavirus.

This therefore leaves most Sub-Saharan African economies with limited policy choices as compared with developed and richer economies. In view of this, the following policy measures are suggested:

- As argued by the IMF (2020), because Sub-Saharan African economies have a weak health system, preservation of health and lives remain a priority. This will help African governments to reduce pressure on public health and personal protection equipment.

- In view of worsening unemployment and increasing poverty levels since the majority of the households who are in informal sectors are extremely vulnerable when governments institute lockdowns measures, there is need for provision of safety nets in the form of cash transfers for the vulnerable people.

- From a monetary policy perspective, as suggest by the IMF (2020), African Central Banks, where inflationary pressures are limited, must remain accommodative. It is important that, where possible, Central Banks provide liquidity to banking sector with a view to ensuring timely processing of all payment transactions and settlements, withdrawals and remittance transfers. In dealing with COVID-19 related shocks, within the macroprudential frameworks, banks must be encouraged to use capital buffers and flexibility to restructure their loan portfolios.

- In line with the recommendations from the African Union, there is need to immediately waiver all interest payments on corporate bonds, trade credits and lease payments. 
- In order to minimise the impact of COVID-19 on businesses, countries must endeavour to create fiscal space with a view to providing both tax deferrals and suspension as well as fiscal incentive packages.

- In order to provide lifeline and safety nets for small businesses, African governments must provide tax exemptions to SMEs.

- In line with the IMF (2020) suggestions, as soon as the COVID-19 pandemic has subsided, Sub-Saharan African economies must, in a sequenced and strategic manner, implement both fiscal and structural reforms which are consistent economic recovery and debt sustainability.

- International assistance, in view of constrained policy and resource space, African countries, in 2020 alone require more than US $\$ 110$ billion to mitigate against the COVID-19 pandemic (IMF, 2020). Although there has been tremendous support from various developmental partners such as the IMF, World Bank and G20 through various financing schemes such as debt relief, debt service suspension, Rapid Credit Facility (RCF) and Rapid Financing Instrument (RFI), which has created more financial space for African economies, there is still a funding gap of US\$44 billion that must be financed. This calls for the need to scale up support for African economies. 
Гифт Мугано ${ }^{1}$

Технолошки универзитет у Дурбану,

Факултет за менаџмент,

Департман за јавни менаџмент и економију

Дурбан (Јужна Африка)

\title{
ЕКОНОМСКА СПОНА ПАНДЕМИЈЕ COVID-19
}

\author{
(Превоg In Extenso)
}

Сажетак: Пандемија COVID-19, која је незапамћена у људској историји, до данас је донела 15,8 милиона потврђених случајева заразе, уз 640,016 смртних исхода, те су владе држава предузеле строге мере затварања. Ово се није одразило само на пословне активности у тим земљама, већ је глобално пореметило ланце вредности, уз немерљиво велике економске импликације. Циљ овог рада је да сагледа утицај пандемије COVID-19 на економију, с посебним освртом на афрички континент. Будући да се пандемија коронавируса и даље мења, те и да је неизвесно колико ће она потрајати, економске импликације пандемије тешко је прецизно квантификовати. Сходно наведеном, за потребе овог рада је примењена анализа сценарија у базном случају, као и богата литература у којој се ова тема обрађује. Резултати показују да је пандемија, иако је због губитака људских живота имала разарајуће друштвене ефекте, такође донела озбиљне економске изазове, међу којима су економска рецесија, смањен обим трговине и знатно ослабљени финансијски токови. Ни Африка, због глобализације, није остала имуна на ове изазове. Како се истиче у овом раду, најзначајније привредне активности и извори девизних средстава у Африци, као што су сектор туризма, извоз разних врста робе, екстерни извори финансирања и локалне пословне активности, претрпели су негативне ефекте у већини афричких економија, што је резултирало рецесијом која је дословно десетковала економску добит стицану у последњих десет година, о чему се изјаснио и Међународни монетарни фонд. У циљу ублажавања ефеката пандемије, афричке земље би требало да користе пакете подстицаја како би сачувале пословање, али и да установе одређене фискалне мере, као што су изузеће од пореза и ангажовање партнера из иностранства који ће им помоћи да изађу из потешкоћа.

Кључне речи: Економија, пандемија COVID-19

\footnotetext{
1 gmugano@gmail.com
} 


\section{1. Увод}

Пандемија коронавируса пријављена је 31. децембра 2019. године у граду Вухан, у кинеској покрајини Хубеи, где је код великог броја пацијената дијагностикована упала плућа непознатог порекла (Програм Уједињених нација за развој, 2020). Од тада је наша планета била сведок ширења коронавируса незамисливих размера, као и болести коју овај вирус изазива, односно COVID-19. Дана 30. јануара и 11. марта 2020. године, услед брзог ширења болести, како у смислу захваћеног географског простора тако и броја заражених/преминулих лица, Светска здравствена организација (С3О) је прогласила глобалну здравствену кризу - јавну здравствену претњу од међународног значаја, односно пандемију (Програм УН, 2020). До 26. јула 2020. број особа код којих је потврђена инфекција порастао је на 15,8 милиона, са 640016 смртних исхода (WHO, 2020).

Имајући у виду природу ове болести, постоје извесне епидемиолошке карактеристике које су и даље нејасне, па је из тог разлога у овом тренутку немогуће са сигурношћу утврдити како ће се пандемија даље одвијати. У овом раду су обрађени економски ефекти пандемије COVID-19, са посебним освртом на афричку економију.

Како се у овом тренутку не располаже са довољно података, уз чињеницу да се пандемија COVID-19 и даље одвија својим током, у овом раду је било тешко квантификовати стварни и потенцијални утицај пандемије. У том погледу, коришћена је расположива литература из угледних извора, као што су Светска банка, Међународни монетарни фонд (ММФ), Програм УН и други релевантни аналитички центри, па се рад највише бави разумевањем могуће економске импликације, као и анализом сценарија, и то у циљу установљавања утицаја пандемије на глобалну економију и афрички континент. Структура рада је следећа: други део обрађује утицај пандемије COVID-19 на глобалну економију, трећи део обрађује утицај пандемије COVID-19 на афричку економију, док су у четвртом делу изнете закључне напомене и приоритети у смислу политика.

\section{2. Тренутни глобални економски контекст}

Пандемија COVID-19 је глобалну економију разорила на досад незабележен начин. Степен разарања економије је огроман и незабележен још од Велике економске кризе из тридесетих година ХХ века, укључујући и скорашњу глобалну економску кризу из 2008. године. Нажалост, све ово се дешава у тренутку када глобална економија и даље с тешком муком настоји да се потпуно опорави од кризе из 2008. године.

Како је наведено, пандемија има разарајуће ефекте и на људски живот, у смислу огромног броја умрлих, чему смо сви били сведоци, као и економских ефеката претрпљених услед прекида глобалних ланаца вредности, који чине приближно 50\% светске трговине, наглог пада цена на робним берзама, наглог пада броја туриста, смањења прилива из иностранства у страној валути и скоро сасвим неактивних тржишта рада, и то све као последица затварања у карантин (African Union, 2020). 


\section{1 Стрмоглави пад цена робе}

Услед изненадног пада потражње и због смањеног интензитета путовања, цене нафте су се суновратиле на 67 долара за барел, што представља пад од преко 54\% (African Union, 2020). Искуства из прошлости показују да пад цена нафте има озбиљне негативне ефекте на економије земаља које производе нафту. На пример, пад цена сирове нафте који је забележен крајем 2014. године за последицу је имао изразито велики пад бруто домаћег производа (БДП) у подсахарској Африци, са 5,1\% у 2014. на 1,4\% у 2016. години. Цене сирове нафте су тада пале за 56\%, и то за само седам месеци (African Union, 2020). Треба нагласити да пошто је током периода од три месеца цена сирове нафте доживела стрмоглави пад за више од $54 \%$, садашњи пад цена сирове нафте се показао као веома брз, што даје суморну слику, односно суморнију од оне из 2014. године. Овде је реч о БДП-у држава које производе нафту.

Међутим, у покушају да се ублаже негативни ефекти константног пада цена сирове нафте, највећи произвођачи сирове нафте су изнели предлог да се до јуна 2020. године производња сирове нафте смањи за 1,5 милиона барела дневно (African Union, 2020). Очекивало се да ће државе које нису чланице ОПЕК-а, као што је Русија, следити овај пример. Нажалост, то се није догодило пошто је Саудијска Арабија 8. марта 2020. године објавила да ће повећати своју производњу, што је довело до ескалације „рата” у производњи нафте, и то тако што су државе које нису чланице ОПЕК-а узвратиле ударац, због чега је дошло до још већег пада цена нафте (African Union, 2020).

\section{2 Ефекти на авио-индустрију и индустрију путовања}

Авио-индустрија је 2019. године забележила рекордну добит од 830 милијарди долара. Да се није догодила пандемија COVID-19, пројекције су биле да би добит од продаје у том сектору у 2020. години износила 872 милијарде долара. Међутим, услед коронавируса, због чега је дошло до наглих затварања у карантин и изузетно строгих ограничења у погледу путовања, Међународна асоцијација за ваздушни превоз (IATA) je 5. марта 2020. године направила пројекцију према којој ће у авио-индустрији вероватни губитак због прекида у саобраћају изазваних пандемијом COVID-19 износити 113 милијарди долара. Најновији статистички подаци показују да се очекује да авио-индустрија и индустрија путовања у 2020. укупно зараде 419 милијарди долара, што представља пад добити од продаје од 50\% у односу на 2019. годину (IATA, 2020).

Исто тако, сектор туризма је суочен са сличним проблемима. Предвиђа се да ће као последица прекида насталих услед пандемије COVID-19 у 2020. години сектор туризма претрпети пад броја туриста између $60 \%$ и $80 \%$, а и у овом региону ће бити забележен пад добити од 910 милијарди долара - 1,2 трилиона долара, тј. скоро две трећине од 1,5 трилиона долара, колико је у 2019. износила добит по основу прилива (Светска туристичка организација при УН/UNWTO, 2020). Када се узму у обзир ранији тржишни трендови, оволико смањење добити представља пет до седам година раста, које ће бити изгубљене као последица пандемије COVID-19. Удружени ефекат овог губитка, из перспективе запослења, је да се предвиђа да ће из индустрије туризма и угоститељства бити отпуштено неколико милиона људи, имајући у виду 
чињеницу да су 80\% компанија које раде у индустрији туризма мала и средња предузећа (МСП), која имају ограничен финансијски капацитет да апсорбују шок изненадног пада добити (UNWTO, 2020).

На глобалном нивоу, хотелијерство и угоститељство ће вероватно изгубити око $20 \%$ своје годишње добити. Ипак, најпосећеније туристичке дестинације, као што су Камбоџа, Вијетнам, Тајланд, Француска, Велика Британија, Италија, САД, Мексико, Кина, Турска и Немачка, при чему у туризму ради сваки десети запослени (319 милиона) у свету, од којих се генерише 10,4\% глобалног БДП-а, због ограничења у погледу путовања вероватно ће изгубити између 40\% и 60\% годишњег промета.

\section{3 Утицај на глобална финансијска тржишта}

Као последица прекида изазваних пандемијом COVID-19, глобална берзанска тржишта претрпела су огромне губитке какве нису имале већ деценијама. На пример, када се одиграла епизода тзв. Црног петка (9. март), берзе, нпр. Dow Jones, су у само једном дану изгубиле близу 3000 поена, док је FTSE пао за око 5\% и само у једном дану направио губитак од невероватних 90 милијарди долара (видети Табелу 1. Слично томе, банкарски сектор је изгубио приближно 40\% своје вредности током само једног месеца, а тренд пада се наставља.

\section{4 Глобална трговина}

Светска трговинска организација (СТО) је 23. јуна 2020. пројектовала да ће се у 2020. обим глобалне трговине вероватно смањити за 18,5\%, али да се побољшање очекује у 2021. години. Ова нова пројекција показује да је СЗО своје предвиђање објављено 8. априла 2020. године ревидирало, и то додатним смањењем. То прво саопштење било је много оптимистичније и предвидело је да би због економских ефеката пандемије COVID-19 обим глобалне трговине могао пасти за 12,9\%, како је приказано у Табели 2

Иако је присутан висок степен неизвесности у погледу дужине трајања и економских ефеката пандемије, СТО сматра да ће утицај пандемије на обим глобалне трговине бити већи од пада обима глобалне трговине који је забележен на врхунцу светске економске кризе из 2008-2009. године (СТО, 2020).

Када је реч о извозу, применом оптимистичног сценарија, како је навела СТО (2020), за Северну Америку се у 2020. години предвиђа рекордни пад извоза од $-17,1 \%$. Слично томе, песимистични сценарио показује да би Северна Америка у 2020. години могла да забележи рекордни пад извоза од 40,9\%. Применом оптимистичног сценарија, предвиђа се да ће Јужна и Централна Америка, Европа, Азија и остали региони забележити пад извоза од -12,9\%, - $12,2 \%,-13,5 \%$ односно -8,0\% (С3О, 2020) (видети Табелу 2).

Исто тако, на основу песимистичног сценарија, предвиђа се да ће укупан увоз у Јужну и Централну Америку, Европу, Азију и остале регионе стрмоглавити и забележити пад од $-33,8 \%,-43,8 \%,-28,9 \%,-31,5 \%$ односно -22,6\% (C3О, 2020) (видети Табелу 2),

Пошто између извоза и раста постоји лабава веза, применом песмистичног сценарија, предвиђа се да ће у свим регионима, односно Северној Америци, Јужној и 
Централној Америци, Европи, Азији и осталим регионима доћи до смањења од -9,0\%, $-11 \%,-10,8 \%,-7,1 \%$ односно $-6,7 \%$ (СТО, 2020) (видети Табелу 2.

У начелу, СТО (2020) изражава мишљење да се током 2021. године може очекивати опоравак глобалне економије, будући да се очекује да ће се и извоз и увоз опоравити, чиме ће бити задржан економски раст.

\section{3. Осврт на утицај пандемије COVID-19 на економију: докази из Африке}

Африка је због глобализације постала интегрисана у светску економију путем међународне трговине, али и миграција. Ови разлози Африку чине изузетно осетљивом на пандемију COVID-19. С тим у вези, Африка трпи и егзогене и ендогене ефекте пандемије (African Union, 2020).

Егзогени ефекти, који представљају екстерне факторе, су последица смањених трговинских токова између Африке и осталих континената, до чега је дошло због знатно мањег броја туриста; дознака, званичне помоћи у развоју, страних директних инвестиција и осталих токова финансирања.

Када је реч о ендогеним ефектима, афрички континент је доживео успорен раст економских активности захваљујући унутрашњим факторима, изазваним тзв. пиковима у ширењу вируса и ограничењима која су увела владе разних држава у циљу спречавања ширења инфекције. На пример, затварање у карантин, које је увела већина влада афричких држава, довело је до озбиљног прекида привредних активности, па самим тим и до пада потражње на домаћим тржиштима и прихода по основу пореза. У одељцима у наставку је приказан утицај пандемије COVID-19 на сектор туризма, цене на робним берзама, извоз, економски раст и екстерне изворе финансирања.

3.1 Смањене пословне активности и број послова у индустријама туризма и путовања у Африци

Будући да су у целом свету била на снази ограничења у погледу путовања, као и затварање у карантин, сектор туризма, који представља једну од окосница економија афричких земаља, претрпео је огромне губитке услед наглог пада у броју туриста. Конкретно, IATA је навела да само авио-превоз у Африци, од којег је процењена добит 55,8 милијарди долара, представља 2,6\% БДП-а у Африци, те да тај сектор запошљава 6,2 милиона људи. Иако је у овом тренутку тешко квантификовати потенцијалне ефекте пандемије COVID-19, ограничења у смислу путовања су се негативно одразила на светске авио-превознике, укључујући и водеће афричке авио-превознике, као што су Ethiopian Airlines, Egypt Air, Kenya Airways, South African Airways итд.

IATA напомиње да је због пандемије COVID-19 и ограничења у погледу путовања која су уследила, отказано $80 \%$ резервација, док су резервације путника из иностранства у Африку током марта и априла 2020. године пале за 20\% (IATA, 2020). Слично томе, резервације у домаћем саобраћају су у марту 2020. пале за 15\%, а у априлу 2020. године за 25\%. Нажалост, између фебруара и марта 2020. године, износ тражених рефундација за авионске карте је порастао за целих 75\%, у поређењу са истим периодом 2019. године (1. фебруар -11. март), што је довело до тога да су афричке авио-компаније претрпеле губитак добити од 4,4 милијарде долара. 
Ниіерија, Еӣиойија, Јужноафричка Рейублика, Кенија и Танзанија. Запослени у туризму чине више од 20\% од укупног броја запослених на Сејшелима, Зеленортским Острвима, Маурицијусу и у Зимбабвеу. Сектор туризма је значајан покретач привреде у овим афричким државама, како директно кроз позитивне курсне разлике тако и кроз ланце вредности и индустрије које су ниже у производном ланцу (African Union, 2020). Конкретно, са становишта отварања нових радних места, сектор туризма апсорбује више од милион људи у свакој од ових земаља: Јужноафричка Република, Кенија, Нигерија, Етиопија и Танзанија (African Union, 2020). Сејшели, Зеленортска Острва, Сао Томе и Принсипе и Маурицијус у сектору туризма запошљавају више од 20\% од укупног броја запосленог становништва (African Union, 2020).

Током недавне кризе, тј. светске економске кризе и шока изазваног ценама на робним берзама 2014. године, туризам у Африци је претрпео значајне губитке, од приближно 7,2 милијарде долара. На темељу овога, применом средњег сценарија, Афричка унија (2020) тврди да ће као последица пандемије COVID-19, сектор туризма и сектор путовања у Африци вероватно изгубити најмање 50 милијарди долара, као и да ће бити укинуто 2 милиона радних места.

\section{2 Извоз из Африке}

Статистички подаци које је недавно објавила Конференција Уједињених нација о трговини и развоју (UNTACD) показују да је током периода 2015-2019. укупан обим трговинске размене у Африци у просеку износио 760 милијарди долара на годишњем нивоу, што представља 29\% БДП-а у Африци. UNTACD у истом извештају наводи да услед ниског нивоа индустријске трансформације, лоше инфраструктуре, ограничене финансијске и монетарне интеграције и постојања широко заступљених препрека, било у форми тарифа или другој форми, трговина међу афричким земљама чини само $17 \%$ укупне трговине у Афричким земљама. Како се $83 \%$ трговине афричких земаља одвија ван афричког континента, економије афричких земаља су изузетно осетљиве на егзогене шокове, као што је пандемија COVID-19.

Занимљиво је напоменути да су највећи трговински партнери афричких земаља Сједињене Америчке Државе, Европска унија и Кина. Делује иронично, како је наведено у Табели 3 да се очекује нагли пад укупног увоза Северне Америке, Јужне и Централне Америке, Европе, Азије и осталих региона од -33,8\%, -43,8\%, -28,9\%, -31,5\% односно -22,6\% (СТО, 2020). Мада је тешко квантификовати шта је тачно утицало на пад извоза у привредама афричких земаља, а као последица огромног пада увоза у наведеним земљама , највећих трговинских партнера, несумњиво је да ће у 2020. години Африка претрпети оштар пад извоза.

Када је реч о извозу сирове нафте, како је наведено у одељку 2.1, цена сирове нафте је драстично пала на мање од 30 долара за барел, што се директно одразило на извоз земаља као што су Алжир, Ангола, Камерун, Чад, Екваторијална Гвинеја, Габон, Гана, Нигерија и Република Конго (African Union, 2020).

Поред овога, не само да је дошло до пада цена, већ је генерално пала потражња за сировом нафтом, што је довело до тога да неке афричке земље које извозе сирову нафту нису могле да је продају. На пример, на дан 4. марта, око 70\% сирове нафте која је натоварена у априлу ове године и која је требало да крене из Анголе и Нигерије и даље није продата, док су друге афричке државе које извозе нафту, нпр. Габон и 
Конго, имале потешкоћа у проналажењу купаца. Јужни Судан и Еритреја су нарочито снажно погођени падом трговине и прекинутим ланцима снабдевања у Кини (Економска комисија Уједињених нација за Африку, UNECA, 2020). Ово је случај управо зато што роба коју увози Кина представља 95\%, односно $58 \%$, робе коју извозе Јужни Судан, односно Еритреја (UNECA, 2020).

Ово је трагична ситуација из два разлога, због смањења цена сирове нафте, као и изненадног шока услед стрмоглавог пада потражње, што има далекосежне последице на економије афричких земаља које извозе нафту.

Међутим, утицај смањеног прихода у страној валути, као последица пада цена сирове нафте, има различите импликације на економије афричких земаља. На пример, извоз нафте у Јужноафричкој Републици чини само 3\% БДП-а, те је имајући ово у виду целокупан ефекат миноран, без обзира на значај који та чињеница има за земљу која је већ у рецесији. Ипак, у земљама као што су Нигерија и Ангола, где извоз нафте представља 90\% укупног извоза и са више од $70 \%$ учествује у националним буџетима, пад цена сирове нафте од преко $54 \%$ ће се вероватно катастрофално одразити на ове економије (UNECA, 2020).

UNECA (2020) је с пуним правом проценила да су очекивани губици повезани са великим падом цена сирове нафте отприлике 65 милијарди долара, од чега се очекује да ће износ губитка само у Нигерији бити до 19 милијарди долара. Ову ситуацију још апсурднијом чини то што је Нигерија свој државни буџет сачинила под претпоставком да ће цена сирове нафте у просеку бити око 67 долара за барел. Пошто је цена пала за више од 54\%, државе које се највише ослањају на извоз нафте су биле приморане да за најмање два квартала смање пројектоване износе добити и редукују расходе (Развојни центар Организације за економску сарадњу и развој, 2020).

Међутим, ово има нето ефекат на смањење девизних резерви у државама које извозе нафту, као и на њихову способност да спроведу своје развојне програме, чији је циљ да ублаже утицај пандемије COVID-19.

Поред трговине сировом нафтом, уочено је да се пандемија COVID-19 негативно одразила и на увоз у афричким земљама. Због прекида производње и застоја у трговини, поједине афричке земље, међу којима су нпр. Јужноафричка Република, Гана и Руанда, доживеле су нагли пад увоза, па је дошло до несташице основних врста робе, које се традиционално увозе из Кине, те је последично уследио нагли скок инфлације у тим државама (African Union, 2020).

\section{3 Спољни извори финансирања Африке}

Током дугог низа година велики број афричких земаља снажно се ослањао на спољне изворе финансирања како би финансирале дебаланс текућих рачуна. Међу неким од спољних извора финансирања су дознаке, стране директне инвестиције, званична помоћ у развоју, задуживање у иностранству и инвестиције у портфолио. Међутим, због очекиване рецесије и економског колапса у земљама из којих финансирање треба да дође, прилив дознака, страних директних инвестиција, инвестиција у портфолија, кредита из иностранства и званична помоћ у развоју ће у Африци вероватно изостати (African Union, 2020). 
(a) Дознаке

Очекује се да ће дознаке, које у последњих десет година у афричким земљама у укупним спољним изворима финансирања континуирано имају удео од приближно једне трећине, драстично пасти због знатно умањене активности у најнапреднијим економијама и економијама у развоју, у којима живи и ради афричка дијаспора. Студије које су спровели Мугано (Mugano, 2018) и Афричка унија (2020) показују да дознаке у БДП-у 13 афричких земаља учествују са више од 5\%, док у неким земљама учествују са чак до $23 \%$ (Лесото) и више од $12 \%$ (Коморска Острва, Гамбија, Либерија). Занимљив је податак да Египат и Нигерија заједно у укупним дознакама у Африци учествују са чак $60 \%$. Предвиђа се да ће ове две државе бити суочене са озбиљним потресима и рањивошћу услед пада дознака из дијаспоре.

(6) Стране директне инвестиције

Конференција Уједињених нација о трговини и развоју (UNCTAD) (2019) је навела да су стране директне инвестиције у афричке земље забележиле расте од $11 \%$, упркос чињеници да су на глобалном нивоу стране директне инвестиције стрмоглаво пале. Ово повећање је у највећој мери допринело расту инвестиција у природне ресурсе и економски опоравак у Јужноафричкој Републици. Према подацима UNCTAD из 2019. године, државе у којима је било највише страних директних инвестиција су: Египат (6,8 милијарди долара, -8,2\%); Јужноафричка Република (5,3 милијарди долара, $+165,8 \%)$, Конго (4,3 милијарде долара, $-2,1 \%)$, Мароко $(3,6 \%$ милијарде долара, $+35,5 \%)$ и Етиопија (3,3 милијарде долара, $-17,6 \%)$.

Са тренутно присутном неизвесношћу у погледу дужине трајања пандемије COVID-19, и уз генерални консензус заснованом на сценарију да ће се пандемија наставити током целе 2020. године, очекује се да ће стране директне инвестиције пасти за између -5\% и 15\%. Потврду за ово добијамо на основу сигнала 100 водећих мултинационалних компанија, како примећује Организација за економску сарадњу и развој, које нам шаљу поруку да постоји озбиљна жеља за смањењем капиталних расхода, у склопу мера ублажавања услед смањених прихода, до чега је дошло због пандемије COVID-19 (UNCTAD, 2020).

Поред тога, привреде афричких земаља, као што је Нигерија, већ су повукле велике износе средстава за капиталне инвестиције. На пример, тзв. All Share Index у Нигерији је у марту 2020. забележио своју најнижу вредност у последњих десет година, и то зато што је дошло до повлачења страних инвеститора. На основу претходне дискусије, пројекције експерата су да би услед пандемије COVID-19, Африка могла да изгуби до 15\% прилива директних страних инвестиција у тај континент.

\section{4 Утицај пандемије COVID-19 на економски раст подсахарске Африке}

Очекује се да ће због негативних ефеката пандемије COVID-19 привреде подсахарских држава током 2020. године пасти за 3,2\%. Међународни монетарни фонд (2020) истиче да ће 2020. економије земаља подсахарске Африке имати БДП мањи за 243 милиона долара, у односу на пројекцију из октобра 2019. године. Оно што је највише утицало на ревидирање пројекција на ниже износе су економије које зависе од туризма, као што су Танзанија, Зимбабве, Коморска Острва и Маурицијус, као и државе које извозе нафту, међу којима предњаче Нигерија и Ангола (ММФ, 2020). 
Интересантно је да се очекује да ће државе као што су Обала Слоноваче, Руанда, Сенегал и Уганда, чија је привреда више диверсификована, издржати негативне ефекте пандемије COVID-19 и очекује се да ће у 2020. години остати позитивне (ММФ, 2020).

Детаљније сагледавање највећих економија подсахарске Африке показује да су Јужноафричка Република, Нигерија и Ангола у рецесији.

Очекује се да ће се економија Јужноафричке Републике смањити за 8\%, углавном као последица економског затварања, које је било на снази од априла до маја 2020. године и чији је циљ био спречавање ширења пандемије COVID-19. Слично томе, очекује се да ће током 2020. реални БДП по глави становника бити мањи за 9,4\%, као резултат прекида рада фирми (видети Табелу 3). Међутим, очекује се да ће ce 2021. године економија Јужноафричке Републике мало опоравити и порасти за 3,5\%, а као резултат раста пословних активности и већег поверења (видети Табелу 3 .

Очекује се да ће се током 2020. економија у Нигерији смањити за 5,4\%, и то услед одсуства добити у страној валути, до чега је дошло због смањене глобалне потражње за сировом нафтом и цене сирове нафте (видети Табелу 3] (ММФ, 2020). Очекује се да ће 2021. године ова земља забележити стопу раста од 2,6\%, потпомогнуто растом глобалне потражње и цена сирове нафте.

Очекује се да ће економија Анголе, попут нигеријске, да опадне за 4\%, услед пада потражње и цена сирове нафте на глобалном нивоу, смањене пословне активности у земљи због затварања у карантин и строгих услова кредитирања (ММФ, 2020). Слично томе, очекује се да ће у 2020. години реални БДП по глави становника бити мањи за 6,8\% (видети Табелу 3). На темељу стабилизовања цена нафте и интензивнијих пословних активности, за 2021. годину се предвиђа раст економије Анголе од 3,25\%.

Све у свему, очекује се да ће у 2020. услед пандемије COVID-19 реални БДП по глави становника пасти за 5,4\%, чиме ће ниво БДП-а по глави становника бити враћен на ниво из 2010. године (ММФ, 2020). ММФ је то формулисао на следећи начин:

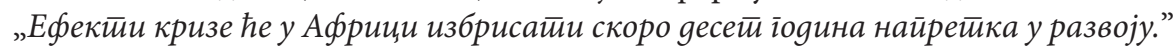

\section{4. Закључак и приоритетне политике}

Пандемија COVID-19 је целом свету несумњиво донела економске и друштвене потешкоће. Ово јесте глобална пандемија, међутим, економије афричких земаља су њоме тешко погођене због сувише јаког ослањања на извоз неколико врста производа, ограничене трговине унутар афричког континента и слабог макроекономског окружења. Да ствари буду још горе, због коронавируса спољни извори финансирања у виду страних директних инвестиција, дознака, инвестиција у портфолије, званичне помоћи у развоју и кредита из иностранства нису нашли пут до Африке у текућој години.

Овим је већини економија земаља подсахарске Африке, у поређењу са развијеним и богатијим економијама, остављен сужен избор у погледу политика. У светлу наведеног, предлажу се следеће мере и политике:

- Како наводи ММФ (2020), будући да економије земаља подсахарске Африке имају слабе системе здравствене заштите, приоритет остаје очување здравља 
и спасавање живота. То ће владама афричких земаља помоћи да смање притисак на систем јавног здравља и набавку личне заштитне опреме.

- Имајући у виду све већу незапосленост и сиромаштво, а зато што је већина домаћинстава чији су чланови запослени у неформалном сектору изузетно угрожена када владе уведу мере затварања у карантин, потребно је обезбедити „сигурносне мреже” у виду готовинских трансфера за угрожено становништво.

- Са становишта монетарне политике, ММФ (2020) сугерише да централне банке афричких земаља у којима су инфлациони притисци ограничени морају остати флексибилне. Важно је да, тамо где је то могуће, централне банке обезбеде ликвидна средства банкарском сектору како би се осигурало да благовремено буду обрађене све платне трансакције и налози, готовина подигнута, а дознаке трансферисане. У борби против шокова повезаних са пандемијом COVID, у макропруденцијалном оквиру, банке је потребно подстаћи да користе заштитне слојеве капитала и примене флексибилност како би реструктурирале своје кредитне портфолије.

- У складу са препорукама Афричке уније, неопходно је одмах се одрећи наплате свих камата на корпоративне обвезнице, комерцијалне кредите и плаћања закупнине.

- Како би се ефекти пандемије COVID-19 на пословање фирми свели на најмању могућу меру, државе морају учинити напор да направе фискални простор, не би ли омогућиле и одлагање у плаћању пореза и обуставу, као и да креирају пакете фискалних стимулација.

- Како би се пружила рука спаса и омогућиле „безбедносне мреже” за мала предузећа, владе афричких земаља морају да за МСП обезбеде изузеће од плаћања пореза.

- У складу са сугестијама ММФ (2020), чим се смањи интензитет пандемије COVID-19, привреде земаља подсахарске Африке морају секвенцијално и стратешки да спроведу и фискалне и структурне реформе, које одговарају економском опоравку и одрживости дуга.

- У светлу лимитираног простора у смислу политика и ресурса, афричким земљама је само у 2020. години потребно више од 110 милијарди долара међународне помоћи да би се ублажили ефекти пандемије COVID-19 (MMФ, 2020). Иако су афричке земље имале огромну подршку различитих развојних партнера, као што су ММФ, Светска банка и Г20, кроз различите шеме финансирања, као што је ослобађање од дуга, привремена обустава сервисирања дуга, „брзи кредити”, тзв. Rapid Credit Facility (RCF), и инструмент брзог финансирања (RFI), којима је створено више финансијског простора за економије афричких земаља, ипак и даље постоји празнина у финансирању од 44 милијарде долара, за шта тек треба обезбедити средства. Све ово захтева интензивирање подршке економијама афричких земаља. 


\section{REFERENCES / ЛИTEPATУPA}

African Union (2020). The Impact of Coronavirus (COVID-19) on the African Economy, Addis Ababa, Ethiopia.

IATA (2020). Industry Loss to Top US\$84 billion in 2020, Geneva, Switzerland.

IMF (2020). Regional Economic Outlook Sub-Saharan Africa: A Cautious Reopening, Washington DC, USA.

IMF (2020). World Economic Outlook, Washington DC, USA.

OECD (March 2020). Interim Economic Assessment Coronavirus: The world economy at risk, Paris France.

UNCTAD (2020). Special edition, Counting the economic costs of coronavirus, 12 March 2020, Geneva (Switzerland).

UNCTAD (2019). Economic Development in Africa 2019, Geneva, Switzerland.

UNCTAD (2019). World Investments Report, Geneva, Switzerland.

UNDP (2020). A Preliminary Assessment of the Socio-economic Impact of Coronavirus (COVID-19) on Zimbabwe, Harare, Zimbabwe.

UNECA (2020). Economic Impact of the Covid19 on Africa, Economic Commission for Africa, Addis Ababa, Ethiopia.

UNWTO (2020). World Tourism Barometer, Geneva, Switzerland.

World Health Organisation (2020), WHO Coronavirus Disease (COVID-19) Dashboard, Geneva, Switzerland.

WTO (2020). Trade Falls Steeply in First Half of 2020, Geneva, Switzerland

WTO (2020). Trade Set to Plunge as COVID-19 Pandemic Upends Global Economy, Geneva, Switzerland. 


\begin{tabular}{|c|c|c|c|c|c|}
\hline 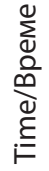 & $\begin{array}{l}\bar{o} \\
\text { ஸֶ. } \\
\text { }\end{array}$ & 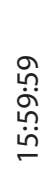 & $\stackrel{\stackrel{n}{m}}{\stackrel{\sim}{\Xi}}$ & 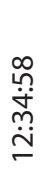 & 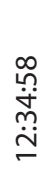 \\
\hline 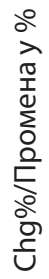 & 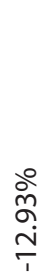 & $\begin{array}{l}\stackrel{0}{0} \\
\text { ọ } \\
\mp\end{array}$ & 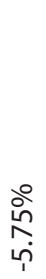 & $\begin{array}{l}\text { ठे } \\
\text { ஸे } \\
\text { مُ }\end{array}$ & $\begin{array}{l}\stackrel{0}{\circ} \\
\stackrel{+}{+}\end{array}$ \\
\hline 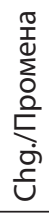 & $\begin{array}{l}\text { 음 } \\
\text { 우 } \\
\text { ㄱ. }\end{array}$ & 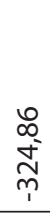 & 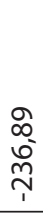 & 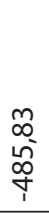 & 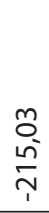 \\
\hline 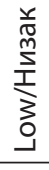 & \begin{tabular}{l}
0 \\
\multirow{6}{0}{} \\
$\frac{0}{0}$ \\
$\dot{0}$
\end{tabular} & 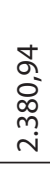 & 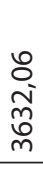 & $\begin{array}{l}\text { 으 } \\
\text { مे } \\
\text { } \\
\infty\end{array}$ & $\begin{array}{l}\text { શ. } \\
\infty \\
\infty \\
\infty \\
\dot{+}\end{array}$ \\
\hline 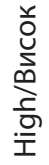 & $\begin{array}{l}\stackrel{\infty}{N} \\
\infty \\
\infty \\
\\
\grave{\sim}\end{array}$ & 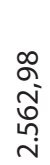 & 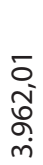 & $\begin{array}{l}8 \\
\infty \\
\infty \\
\infty \\
\infty \\
\infty\end{array}$ & $\begin{array}{l}\bar{\sigma} \\
\overline{6} \\
\text { n̊ } \\
\text { in }\end{array}$ \\
\hline 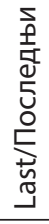 & $\begin{array}{l}\text { N } \\
\infty \\
\infty \\
\infty \\
\stackrel{0}{0}\end{array}$ & $\begin{array}{l}0 \\
\sigma \\
\infty \\
m \\
\sim\end{array}$ & \begin{tabular}{l} 
O \\
\multirow{-}{\infty}{} \\
$\infty$ \\
$\infty$ \\
$\dot{m}$
\end{tabular} & $\begin{array}{l}\stackrel{+}{N} \\
\infty\end{array}$ & $\begin{array}{l}\stackrel{\infty}{0} \\
\text { in } \\
\text { in }\end{array}$ \\
\hline 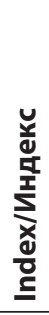 & $\begin{array}{l}\text { ㅇ } \\
3 \\
\text { zo } \\
\text { ○ }\end{array}$ & 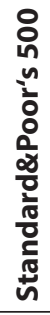 & 巳্ণ & $\stackrel{x}{a}$ & $\frac{8}{\frac{8}{4}}$ \\
\hline
\end{tabular}


Гифт Мугано, Економска сйона йанgемије COVID-19

Table 2: WTO April Forecast: Merchandise Trade Volume and Real GDP 2018-2021 /

Табела 2: Предвиђање СТО из месеца априла: Обим трговинске размене и реални БДП 2018-2021.

\begin{tabular}{|c|c|c|c|c|c|c|}
\hline \multicolumn{7}{|c|}{ Annual Percentage Change/Промена йроценш̄а на їоgишњем нивоу } \\
\hline \multirow{2}{*}{ Description/Опис } & \multicolumn{2}{|c|}{$\begin{array}{l}\text { Historical/ } \\
\text { Историјски }\end{array}$} & \multicolumn{2}{|c|}{$\begin{array}{c}\text { Optimistic/ } \\
\text { Оптимистичан }\end{array}$} & \multicolumn{2}{|c|}{$\begin{array}{c}\text { Pessimistic/ } \\
\text { Песимистичан }\end{array}$} \\
\hline & 2018 & 2019 & 2020 & 2021 & 2020 & 2021 \\
\hline $\begin{array}{l}\text { Volume of World Trade } \\
\text { Merchandise Trade/ } \\
\text { Обим трговинске } \\
\text { размене у свету }\end{array}$ & $2.9 \%$ & $-0.1 \%$ & $-12.9 \%$ & $21.3 \%$ & $-31.9 \%$ & $24.0 \%$ \\
\hline Exports/Извоз & 2018 & 2019 & 2020 & 2021 & 2020 & 2021 \\
\hline $\begin{array}{l}\text { North America/ } \\
\text { Северна Америка }\end{array}$ & 3,8 & 1,0 & $-17,1$ & 23,7 & $-40,9$ & 19,3 \\
\hline $\begin{array}{l}\text { South and Central } \\
\text { Аmerica/Јужна и } \\
\text { Централна Америка }\end{array}$ & 0,1 & $-2,2$ & $-12,9$ & 18,6 & $-31,3$ & 14,3 \\
\hline Europe/Европа & 2,0 & 0,1 & $-12,2$ & 20,5 & $-32,8$ & 22,7 \\
\hline Asia/Азија & 3,7 & 0,9 & $-13,5$ & 24,9 & $-36,2$ & 36,1 \\
\hline $\begin{array}{l}\text { Other Regions/Остали } \\
\text { региони }\end{array}$ & 0,7 & $-2,9$ & $-8,0$ & 8,6 & $-8,0$ & 9,3 \\
\hline Imports/Увоз & 2018 & 2019 & 2020 & 2021 & 2020 & 2021 \\
\hline $\begin{array}{l}\text { North America/ } \\
\text { Северна Америка }\end{array}$ & 5,2 & $-0,4$ & $-14,5$ & 27,3 & $-33,8$ & 29,5 \\
\hline $\begin{array}{l}\text { South and Central } \\
\text { Аmerica/Јужна и } \\
\text { Централна Америка }\end{array}$ & 5,3 & $-2,1$ & $-22,2$ & 23,2 & $-43,8$ & 19,5 \\
\hline Europe/Европа & 1,5 & 0,5 & $-10,3$ & 19,9 & $-28,9$ & 24,5 \\
\hline Asia/Азија & 4,9 & $-0,6$ & $-11,8$ & 23,1 & $-31,5$ & 25,1 \\
\hline $\begin{array}{l}\text { Other Regions/Остали } \\
\text { региони }\end{array}$ & 0,3 & 1,5 & -10 & 13,6 & $-22,6$ & 18,0 \\
\hline 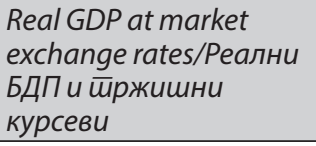 & 2,9 & 2,3 & $-2,5$ & 7,4 & $-8,8$ & 5,9 \\
\hline $\begin{array}{l}\text { North America/ } \\
\text { Северна Америка }\end{array}$ & 2,8 & 2,2 & $-3,3$ & 7,2 & $-9,0$ & 5,1 \\
\hline $\begin{array}{l}\text { South and Central } \\
\text { Аmerica/Јужна и } \\
\text { Централна Америка }\end{array}$ & 0,6 & 0,1 & $-4,3$ & 6,5 & -11 & 4,8 \\
\hline Europe/Европа & 2,1 & 1,3 & $-3,5$ & 6,6 & $-10,8$ & 5,4 \\
\hline Аsia/Азија & 4,2 & 3,9 & $-0,7$ & 8,7 & $-7,1$ & 7,4 \\
\hline $\begin{array}{l}\text { Other Regions/Остали } \\
\text { региони }\end{array}$ & 2,1 & 1,7 & $-1,5$ & 6,0 & $-6,7$ & 5,2 \\
\hline
\end{tabular}

Source: World Trade Organisation (2020) / Извор: Светска трговинска организација (2020) 
Table 3: Real GDP and Real GDP per Capita Growth /

Табела 3: Реални БДП и раст реалног БДП-а по глави становника

\begin{tabular}{|c|c|c|c|c|c|c|c|c|}
\hline \multirow[b]{3}{*}{ Country/Држава } & \multicolumn{4}{|c|}{$\begin{array}{l}\text { Real GDP Growth/Pact } \\
\text { реалног БДП-а }\end{array}$} & \multicolumn{4}{|c|}{$\begin{array}{l}\text { Real GDP per Capita Growth/ } \\
\text { Раст реалног БДП-а по глави } \\
\text { становника }\end{array}$} \\
\hline & \multicolumn{2}{|c|}{\begin{tabular}{|c|} 
Historical// \\
Историјски (\%)
\end{tabular}} & \multicolumn{2}{|c|}{$\begin{array}{c}\text { Projections/ } \\
\text { Пројекције (\%) }\end{array}$} & \multicolumn{2}{|c|}{$\begin{array}{c}\text { Historical/ } \\
\text { Историјски (\%) }\end{array}$} & \multicolumn{2}{|c|}{$\begin{array}{c}\text { Projections/ } \\
\text { Пројекције (\%) }\end{array}$} \\
\hline & 2018 & 2019 & 2020 & 2021 & 2018 & 2019 & 2020 & 2021 \\
\hline Angola/Ангола & $-1,2$ & $-0,9$ & $-4,0$ & 3,2 & $-4,2$ & $-3,8$ & $-6,8$ & 0,2 \\
\hline Benin/Бенин & 6,7 & 6,9 & 2,2 & 6,0 & 3,8 & 3,9 & $-0,6$ & 3,1 \\
\hline Botswana/Боцвана & 4,5 & 3,0 & $-9,6$ & 8,6 & 2,6 & 1,1 & $-11,2$ & 6,7 \\
\hline $\begin{array}{l}\text { Burkina Faso/ } \\
\text { Буркина Фасо }\end{array}$ & 6,8 & 5,7 & 0,9 & 4,7 & 3,8 & 2,7 & $-1,9$ & 1,7 \\
\hline Burundi/Бурунди & 1,6 & 1,8 & $-5,5$ & 4,2 & $-1,3$ & $-1,2$ & $-8,3$ & 1,2 \\
\hline $\begin{array}{l}\text { Cape Verde/ } \\
\text { Зеленортска Острва }\end{array}$ & 4,5 & 5,7 & $-5,5$ & 5,0 & 5,0 & 4,4 & $-6,7$ & 3,8 \\
\hline Cameroon/Камерун & 4,1 & 3,7 & $-3,5$ & 3,3 & 1,5 & 1,2 & $-5,9$ & 0,8 \\
\hline $\begin{array}{l}\text { CAR/Централноафричка } \\
\text { Република }\end{array}$ & 3,8 & 3,0 & $-1,0$ & 3,0 & 2,3 & 1,3 & $-2,7$ & 1,1 \\
\hline Chad/Чад & 2,3 & 3,0 & $-0,8$ & 6,2 & $-0,7$ & $-0,1$ & $-3,7$ & 3,1 \\
\hline $\begin{array}{l}\text { Comoros/ } \\
\text { Коморска Острва }\end{array}$ & 3,6 & 1,9 & $-6,0$ & 2,7 & 0,9 & $-0,8$ & $-8,5$ & 0,0 \\
\hline $\begin{array}{l}\text { DRC/Демократска } \\
\text { Република Конго }\end{array}$ & 5,8 & 4,4 & $-2,2$ & 3,5 & 2,7 & 1,3 & $-5,1$ & 0,5 \\
\hline $\begin{array}{l}\text { Cote d/lvoire/ } \\
\text { Обала Слоноваче }\end{array}$ & 6,8 & 6,9 & 1,8 & 6,2 & 4,1 & 4,2 & $-0,8$ & 3,5 \\
\hline $\begin{array}{l}\text { Equatorial Guinea/ } \\
\text { Екваторијална Гвинеја }\end{array}$ & $-5,8$ & $-6,1$ & $-8,1$ & 2,5 & $-9,1$ & $-9,3$ & $-11,2$ & $-0,7$ \\
\hline Eritrea/Еритреја & 13,0 & 3,8 & $-0,6$ & 5,7 & 11,7 & 2,5 & $-2,0$ & 4,1 \\
\hline Eswatini/Свазиленд & 2,4 & 1,1 & $-3,5$ & 1,4 & 1,3 & 0,2 & $-4,5$ & 0,3 \\
\hline Ethiopia/Етиопија & 7,7 & 9,0 & 1,9 & 0,0 & 6,0 & 6,2 & 0,3 & $-1,6$ \\
\hline Gabon/Габон & 1,0 & 3,8 & $-0,9$ & 2,1 & $-0,4$ & 2,4 & $-2,2$ & 0,8 \\
\hline Gambia/Гамбија & 7,0 & 6,2 & $-1,5$ & 7,0 & 3,9 & 3,1 & $-4,4$ & 3,9 \\
\hline Ghana/Гана & 6,3 & 6,1 & 1,5 & 5,9 & 4,1 & 4,0 & $-0,5$ & 4,2 \\
\hline Guinea/Гвинеја & 6,2 & 5,6 & 1,4 & 6,6 & 3,6 & 3,1 & $-1,0$ & 4,0 \\
\hline $\begin{array}{l}\text { Guinea-Bissau/ } \\
\text { Гвинеја Бисао }\end{array}$ & 3,4 & 4,5 & $-1,9$ & 4,0 & 1,1 & 2,3 & $-4,0$ & 1,8 \\
\hline
\end{tabular}


Гифт Мугано, Економска сйона йанgемије COVID-19

\begin{tabular}{|c|c|c|c|c|c|c|c|c|}
\hline Kenya/Кенија & 6,3 & 5,4 & $-0,3$ & 4,0 & 3,8 & 2,9 & $-2,5$ & 1,7 \\
\hline Lesotho/Лесото & 0,4 & 0,9 & $-4,5$ & 3,5 & $-0,3$ & 0,3 & $-5,2$ & 2,3 \\
\hline Liberia/Либерија & 1,2 & $-2,5$ & $-2,5$ & 4,0 & $-1,3$ & $-4,9$ & $-4,9$ & 1,5 \\
\hline Madagascar/Мадагаскар & 4,6 & 4,8 & $-1,0$ & 4,2 & 1,9 & 2,1 & $-3,5$ & 1,6 \\
\hline Malawi/Малави & 3,2 & 4,5 & 1,0 & 2,5 & 0,3 & 1,6 & $-1,8$ & $-0,4$ \\
\hline Mali/Мали & 5,2 & 5,1 & 0,0 & 5,5 & 2,1 & 2,0 & $-2,9$ & 2,4 \\
\hline Mauritius/Маурицијус & 3,8 & 3,5 & $-12,2$ & 8,9 & 3,7 & 3,4 & $-12,2$ & 8,9 \\
\hline Mozambique/Мозамбик & 3,4 & 2,2 & 1,4 & 4,2 & 0,7 & $-0,5$ & $-1,3$ & 1,5 \\
\hline Namibia/Намибија & 0,7 & $-1,1$ & $-6,0$ & 3,6 & $-1,2$ & $-3,0$ & $-7,8$ & 1,6 \\
\hline Niger/Нигер & 7,0 & 5,5 & 0,5 & 6,9 & 3,0 & 1,6 & $-3,2$ & 3,0 \\
\hline Nigeria/Нигерија & 1,9 & 2,2 & $-5,4$ & 2,6 & $-0,7$ & $-0,4$ & $-7,8$ & 0,1 \\
\hline Rwanda/Руанда & 8,6 & 9,4 & 2,0 & 6,3 & 5,9 & 6,8 & $-0,1$ & 3,9 \\
\hline $\begin{array}{l}\text { Sao Tome \& Principe/ } \\
\text { Сао Томе и Принсипе }\end{array}$ & 3,0 & 1,3 & $-6,5$ & 3,0 & 0,6 & $-0,6$ & $-8,6$ & 0,7 \\
\hline Senegal/Сенегал & 6,4 & 5,3 & 1,3 & 4,0 & 3,4 & 2,4 & $-1,5$ & 1,1 \\
\hline Seychelles/Сејшели & 3,8 & 3,9 & $-13,8$ & 4,2 & 2,6 & 2,9 & $-14,5$ & 3,3 \\
\hline $\begin{array}{l}\text { Sierra Leone/Сијера } \\
\text { Леоне }\end{array}$ & 3,5 & 5,1 & $-3,1$ & 2,7 & 1,3 & 2,9 & $-5,1$ & 0,6 \\
\hline $\begin{array}{l}\text { South Africa/ } \\
\text { Јужноафричка } \\
\text { Република }\end{array}$ & 0,8 & 0,2 & $-8,0$ & 3,5 & $-0,7$ & $-1,3$ & $-9,4$ & 1,9 \\
\hline $\begin{array}{l}\text { South Sudan/Јужни } \\
\text { Судан }\end{array}$ & $-1,1$ & 11,3 & 4,7 & $-1,0$ & $-4,1$ & 7,9 & 1,6 & $-4,0$ \\
\hline Tanzania/Танзанија & 7,0 & 6,3 & 1,9 & 3,6 & 3,8 & 3,2 & $-1,0$ & 0,6 \\
\hline Togo/Того & 4,9 & 5,3 & 1,0 & 4,0 & 2,3 & 2,7 & $-1,5$ & 1,4 \\
\hline Uganda/Уганда & 6,3 & 4,5 & 1,8 & 2,6 & 3,2 & 1,9 & $-1,6$ & $-0,4$ \\
\hline Zambia/Замбија & 4,0 & 1,5 & $-5,1$ & 0,6 & 0,9 & $-1,5$ & $-7,9$ & $-2,4$ \\
\hline Zimbabwe/Зимбабве & 3,5 & $-6,5$ & $-10,4$ & 4,2 & 2,0 & $-8,2$ & $-12,1$ & 2,1 \\
\hline $\begin{array}{l}\text { SSA/Подсахарска } \\
\text { Африка }\end{array}$ & 3,2 & 3,1 & $-3,2$ & 3,4 & 0,9 & 0,7 & $-5,4$ & 1,1 \\
\hline
\end{tabular}

Source: IMF, World Economic Outlook Database / Извор: ММФ, база података Светске економске перспективе 